\title{
Superoxide Dismutase in Polymorphonuclear Leukocytes of Term Newborn Infants and Very Low Birth Weight Infants
}

\author{
MASAAKI KUGO, KIMIHIKO SANO, YOSHIYUKI UETANI, AND HAJIME NAKAMURA
}

Department of Pediatrics, Kobe University School of Medicine, Kobe, Japan

\begin{abstract}
We investigated the activity and the content of copper and zinc-containing superoxide dismutase (SOD) and superoxide anion $\left(\mathrm{O}_{2}^{-}\right)$production in polymorphonuclear leukocytes (PMN) from healthy term newborn infants, very low birth wt infants, and healthy adults. SOD activity in PMN was measured with nitroblue tetrazolium reduction assay on PAGE, and the SOD content in PMN was determined with an ELISA using a monoclonal antibody against human copper and zinc-containing SOD. The activity and the content of SOD in the term neonatal PMN and VLBW-infants' PMN were significantly lower than those in the adults' PMN (term newborn infants, $6.6 \pm 0.6$ $\mathrm{U} / \mathrm{mg}$ protein and $170.4 \pm 16.3 \mathrm{ng} / \mathrm{mg}$ protein, $n=10$; VLBW infants, $6.8 \pm 0.9$ and $173.0 \pm 16.2, n=6$; adults, $10.3 \pm 0.6$ and $241.9 \pm 13.3, n=10$; values were expressed as mean \pm SEM). Both the phorbol myristate acetate- and the $\mathrm{N}$-formyl-methionyl-leucyl-phenylalanine-induced $\mathrm{O}_{2}^{-}$ production rates of VLBW-infants' PMN were significantly higher than those of the term neonatal PMN. The phorbol myristate acetate-induced $\mathrm{O}_{2}^{-}$production rate of the term neonatal PMN was significantly lower than that of the adults' PMN. The phorbol myristate acetate-induced $\mathrm{H}_{2} \mathrm{O}_{2}$ production rate of the term neonatal PMN was significantly lower than that of the adults' PMN. The conversion rate from $\mathrm{O}_{2}^{-}$to $\mathrm{H}_{2} \mathrm{O}_{2}$ of the neonatal PMN was similar to that of the adults' PMN. These findings suggest that neonatal PMN have an equal ability to convert $\mathrm{O}_{2}^{-}$to $\mathrm{H}_{2} \mathrm{O}_{2}$ to an adult's PMN, although the neonatal PMN had a lower SOD activity than the adults' PMN. In addition, the decreased oxygen metabolites production of the term neonatal PMN helps account for their defective bactericidal activity. (Pediatr Res 26:227-231, 1989)
\end{abstract}

\section{Abbreviations}

VLBW infants, very low birth wt infants

PMN, polymorphonuclear leukocyte

$\mathrm{O}_{2}{ }^{-}$, superoxide anion

SOD, superoxide dismutase

$\mathrm{Cu}, \mathrm{Zn}-\mathrm{SOD}$, copper and zinc-containing superoxide dismutase

PMA, phorbol myristate acetate

FMLP, N-formyl-methionyl-leucyl-phenylalanine

NBT, nitroblue tetrazolium

Received December 30, 1988; accepted May 16, 1989

Correspondence Masaaki Kugo, Department of Pediatrics, Kobe University School of Medicine, 7-chome, Kusunoki-cho, Chuo-ku, Kobe, Japan.

Supported in part by the Grant-in-Aid 63770648 for Scientific Research from the Ministry of Education, Culture and Science in Japan (1988).
Newborn infants are susceptible to bacterial infection, and premature infants weighing less than $1500 \mathrm{~g}$ (VLBW infants) are even more susceptible than term infants. PMN play a primary role in the host defense system against bacterial infection. The respiratory burst, characterized by increased oxygen consumption, an increase in hexose monophosphate shunt activity, and an increased production of oxygen metabolites such as $\mathrm{O}_{2}{ }^{-}$, $\mathrm{H}_{2} \mathrm{O}_{2}$, hydroxyl radical, and singlet oxygen, occurs upon the activation of PMN (1). These oxidant species are used as antimicrobial agents.

Defective bactericidal activity in PMN of normal newborn infants was described when the concentration of an opsonizing serum was reduced to $2 \%$ (2) or bacteria to the PMN ratio was large in the assay condition (3). And PMN of infants less than $12 \mathrm{~h}$ of age (4), preterm infants (5), and stressed newborn infants $(6,7)$ also have been reported to have defective bactericidal function.

$\mathrm{O}_{2}^{-}$production is the key reaction in the initiation of the respiratory burst. The results of previous investigations of the $\mathrm{O}_{2}{ }^{-}$production rate of neonatal PMN have been varied $(8-12)$, and there has been no report describing the $\mathrm{O}_{2}{ }^{-}$production of PMN obtained from VLBW infants.

PMN contain two distinct types of SOD, namely, a $\mathrm{Cu}, \mathrm{Zn}$ SOD localized in the cytosol, and a manganese-containing SOD in mitochondria (13). $\mathrm{O}_{2}^{-}$, which has negligible antimicrobial activity itself (14), is dismutated spontaneously or enzymatically by $\mathrm{Cu}, \mathrm{Zn}$-SOD in the cytosol of PMN to generate $\mathrm{H}_{2} \mathrm{O}_{2}$ and oxygen (15) $\mathrm{H}_{2} \mathrm{O}_{2}$ has substantial bactericidal activity (16), and current evidence strongly suggests that hypochlorite, which is produced by the oxidation of $\mathrm{Cl}^{-}$by $\mathrm{H}_{2} \mathrm{O}_{2}$, and hydroxyl radical, the product of the interaction between $\mathrm{O}_{2}^{-}$and $\mathrm{H}_{2} \mathrm{O}_{2}$, are critically important antimicrobial oxidants generated in PMN (14, 17, 18). SOD in PMN also protects cells from self-inflicted oxidative injury by detoxifying $\mathrm{O}_{2}{ }^{-}$, but there has been very little information about the content or the activity of SOD in PMN of the neonates.

In our study, we have measured both the activity and the content of SOD in PMN of healthy term newborn infants and VLBW infants. In addition, we have evaluated the $\mathrm{O}_{2}{ }^{-}$production rate of PMN of term newborn infants and VLBW infants.

\section{MATERIALS AND METHODS}

Reagents. Cytochrome C (Type VI), PMA, FMLP, NBT, riboflavin, $\mathrm{Cu}, \mathrm{Zn}-\mathrm{SOD}$ (human erythrocytes), scopoletin, and horseradish peroxidase (type VI) were obtained from Sigma Chemical Co. (St. Louis, MO). Mouse antihuman $\mathrm{Cu}, \mathrm{Zn}$-SOD $\mathrm{mAb}$ and affinity-purified SOD were obtained from Ube Industries (Tokyo, Japan)

Study Population. For the determination of $\mathrm{Cu}, \mathrm{Zn}-\mathrm{SOD}$ in PMN, 10 healthy term newborn infants and six VLBW infants, all of whom were within $24 \mathrm{~h}$ after birth, and 10 healthy adults 
were studied. The mean birth wt of the healthy term newborn infants was $3186 \mathrm{~g}$ (range 2790-3576 g), and that of the VLBW infants was $1235 \mathrm{~g}$ (range 798-1486 $\mathrm{g}$ ). The mean gestational age of the VLBW infants was 29 wk (range 25-32 wk). Diagnoses of the VLBW infants included four infants with respiratory distress syndrome, one with apnea, and one with hypoglycemia.

The $\mathrm{O}_{2}^{-}$production rates were studied in PMN obtained from 12 healthy term newborn infants at 0,3 , and $6 \mathrm{~d}$ of age, 12 VLBW infants at 0,6 , and $30 \mathrm{~d}$ of age, and 19 healthy adults. The mean birth wt and the gestational age of the VLBW infants studied were $1084 \mathrm{~g}$ (range 789-1470 g) and $30 \mathrm{wk}$ (range 25$35 \mathrm{wk}$ ), respectively. The population of the VLBW infants was as follows: five infants with respiratory distress syndrome, four infants with apnea, two infants with hypoglycemia, and the other with aspiration syndrome.

Isolation of PMN. One $\mathrm{mL}$ of heparinized blood was drawn from the vein and PMN were isolated by means of dextran sedimentation, centrifugation through Lymphoprep (Nycomed AS, Oslo, Norway) followed by hypotonic lysis of erythrocytes. Isolated cells, at more than $95 \%$ purity, were resuspended in PBS consisting of $10 \mathrm{mM}$ phosphate $(\mathrm{pH} 7.4), 137 \mathrm{mM} \mathrm{NaCl}$, and $2.7 \mathrm{mM} \mathrm{KCl}$. The cell viability determined by trypan blue dye exclusion was always more than $95 \%$ throughout the experiments in this study.

Preparation of PMN Homogenate. Isolated cells suspended in PBS at pH $7.4\left(1 \times 10^{7} \mathrm{PMN} / \mathrm{mL}\right)$ were sonicated for $45 \mathrm{~s}$ on ice with a sonifier cell disruptor (Kontes, Vineland, NJ) at maximum intensity and then centrifuged for $15 \mathrm{~min}$ at $1200 \times$ $g$ at $4^{\circ} \mathrm{C}$. The resulting supernatant was used for enzyme assays. The protein concentration in the samples was determined by the method of Lowry et al. (19) using BSA as a standard.

Measurement of Activity and Content of SOD. Photochemical $N B T$ reduction assay on polyacrylamide gel electropherograms. The PMN homogenates ( $20 \mu \mathrm{g}$ protein) were electrophoresed on $10 \%$ polyacrylamide gel as described by Laemli (20) at a constant current at $20 \mathrm{~mA}$, except SDS was omitted from the gel and the buffer. The activity staining procedure for SOD was performed as described by Salin and McCord (13). Although in the dark for $40 \mathrm{~min}$, the gel was soaked in $50 \mathrm{mM}$ potassium phosphate buffer at $\mathrm{pH} 7.8$ containing $1 \mathrm{mM}$ EDTA, $0.25 \mathrm{mM}$ NBT, 20 $\mathrm{mM}$ tetramethylethylenediamine, and $30 \mu \mathrm{M}$ riboflavin.

After the soaking period, the gel was rinsed briefly with distilled water and exposed to an incandescent desk lamp for $15 \mathrm{~min}$. During illumination the gel became uniformly purple except at the positions containing SOD. The gel was scanned at $560 \mathrm{~nm}$ with linear scanning densitometry using a Dual-wavelength TLC Scanner (CS-930, Shimadzu, Kyoto, Japan), and the areas under the troughs, which correspond with the bands of activity, were determined by weighing the tracing paper. $\mathrm{Cu}, \mathrm{Zn}-\mathrm{SOD}$ from human erythrocytes (Sigma) was used as a standard in each assay. SOD activity was expressed as $\mathrm{U} / \mathrm{mg}$ protein.

ELISA using $M A b$. Flat-bottomed 96-well microtiter plates were coated with affinity-purified mouse antihuman $\mathrm{Cu}, \mathrm{Zn}$-SOD (N-4). The homogenates of PMN diluted by distilled water to a concentration of about $200 \mu \mathrm{g}$ protein $/ \mathrm{mL}$ were then added to the wells (100 $\mu \mathrm{L} /$ well in duplicate), and incubated for $2 \mathrm{~h}$ at room temperature. Each plate also included 10 serial 2-fold dilutions of affinity-purified SOD standard (Ube Industries) ranging between 0 and $40 \mathrm{ng} /$ well.

These were then washed three times with PBS at $\mathrm{pH} 7.4$ containing $0.1 \%$ Tween 20 , and the wells were filled with 100 $\mu \mathrm{L}$ of peroxidase-conjugated, affinity-purified mouse $\mathrm{F}\left(\mathrm{ab}^{\prime}\right)_{2}$ antihuman $\mathrm{Cu}, \mathrm{Zn}$-SOD-(N-6). After $2 \mathrm{~h}$ incubation at room temperature, the plates were again washed three times with PBSTween 20 solution, and subsequently $100 \mu \mathrm{L}$ of $0.44 \mathrm{mg} / \mathrm{mL} o_{-}$ phenilenediamine dihydrochloride in citrate buffer at $\mathrm{pH} 5.0$ with $0.007 \% \mathrm{H}_{2} \mathrm{O}_{2}$ was added to each well. After a $15-\mathrm{min}$ incubation in the dark at room temperature, the reaction was stopped by the addition of $50 \mu \mathrm{L}$ of $2 \mathrm{~N}$-hydrochloric acid.

Optical density of each well was measured at $492 \mathrm{~nm}$ using a
Titertek Uniskan (Labsystems and Flow Laboratories, Finland). Values were determined by reference to a standard line. The content of SOD was expressed as $\mathrm{ng} / \mathrm{mg}$ protein.

Measurement of $\mathrm{O}_{2}{ }^{-}$Production. Spectrophotometric measurement of $\mathrm{O}_{2}{ }^{-}$-dependent cytochrome $\mathrm{C}$ reduction was performed in a special double-beam spectrophotometer with different circuits of 550 and $540 \mathrm{~nm}$ equipped with a thermoregulator set at $37^{\circ} \mathrm{C}$ (model SA-1, Arrows, Osaka, Japan) as described previously (21). The sample cuvette contained $20 \mu \mathrm{M}$ ferricytochrome C, $1 \times 10^{5}$ cells of PMN, and $5 \mathrm{mM}$ glucose in $1 \mathrm{~mL}$ of PBS at $\mathrm{pH}$ 7.4. PMN were stimulated by either PMA $(0.1 \mu \mathrm{g} /$ $\mathrm{mL}$ ) or FMLP (4 nM). The rate of cytochrome $C$ reduction was measured by the change of absorbance at 550-540 nm.

When PMA was used as a stimulant, the linear change of the absorbance was observed between 2 and 4 min after the addition of the agent and the absorbance continued to increase over 10 min at the lower rate. When FMLP was used as a stimulant, the absorbance reached the plateau level $3 \mathrm{~min}$ after the addition of the agent. Thus, the $\mathrm{O}_{2}{ }^{-}$production rates were calculated from the linear slope of cytochrome $\mathrm{C}$ reduction for PMA and from the amount of cytochrome $\mathrm{C}$ reduced in $3 \mathrm{~min}$ for FMLP using an absorbance coefficient of cytochrome $C$ at $\mathrm{OD}_{550-540}$ of 19.1 . The $\mathrm{O}_{2}{ }^{-}$production rate was expressed as $\mathrm{nmol} / \mathrm{min} / 10^{6} \mathrm{PMN}$ for PMA-stimulated cells and $\mathrm{nmol} / 3 \mathrm{~min} / 10^{6} \mathrm{PMN}$ for FMLPstimulated cells.

Measurement of $\mathrm{H}_{2} \mathrm{O}_{2}$ Release. $\mathrm{H}_{2} \mathrm{O}_{2}$ production by PMN was determined by measuring the decreased fluorescence of scopoletin (22). The sample cuvette contained $2 \mu \mathrm{M}$ scopoletin, 20 $\mathrm{nM}$ horseradish peroxidase, $5 \times 10^{5}$ cells of $\mathrm{PMN}$, and $5 \mathrm{mM}$ glucose in $2 \mathrm{~mL}$ of Krebs-Ringer bicarbonate buffer at $\mathrm{pH} 7.4$.

Fluorescence was measured using the fluorescence spectrophotometer (650-10S, Hitachi, Tokyo, Japan) equipped with the thermoregulator set at $37^{\circ} \mathrm{C}$ and a magnetic stirring device. Peak excitation and emission wave lengths were determined to be 355 and $460 \mathrm{~nm}$, respectively. $\mathrm{H}_{2} \mathrm{O}_{2}$ standard solutions $(0-2 \mu \mathrm{M})$ were prepared just before the measurement using a molar extinction coefficient of 81 at $230 \mathrm{~nm}$. The intensity of the emission fluorescence was recorded continuously on the Hitachi recorder type 561, and the rate of $\mathrm{H}_{2} \mathrm{O}_{2}$ release after the addition of PMA $(0.1 \mu \mathrm{g} / \mathrm{mL})$ was calculated from the linear portion of reduced scopoletin.

Statistical Analysis. Statistical analysis was performed using Student's $t$ test except that the Wilcoxon rank sum test was used in the experiments of $\mathrm{O}_{2}^{-}$production rate of PMN. Possible relationships between SOD activity and SOD content in individual samples were investigated with linear regression analysis.

\section{RESULTS}

Activity and content of SOD in PMN. SOD dismutates $\mathrm{O}_{2}{ }^{-}$to generate $\mathrm{H}_{2} \mathrm{O}_{2}$, not only to produce potent antimicrobial agents such as hydroxyl radical and hypochlorite, but also to protect the PMN membrane from $\mathrm{O}_{2}{ }^{-}$toxicity. Strauss et al. (23) reported that the neonatal PMN had a similar content of SOD to the adults' PMN, but they used a xanthine oxidase-cytochrome $\mathrm{C}$ assay which is highly affected by SOD-insensitive cytochrome $\mathrm{C}$ reduction (24). Therefore we used polyacrylamide gel-NBT reduction assay and ELISA using a MAb against human $\mathrm{Cu}, \mathrm{Zn}$ SOD to eliminate the influence of other factors in the measurement of SOD.

In the NBT reduction assay on PAGE, the photogenerated $\mathrm{O}_{2}{ }^{-}$reduced NBT to form insoluble purple formazan except for an achromatic band at the position of SOD activity. Figure $1 \mathrm{~A}$ represents the typical densitometric scans of the stained gel. When the areas under the troughs, which correspond with the bands of human erythrocyte $\mathrm{Cu}, \mathrm{Zn}$-SOD activity, were plotted against the amount of SOD applied, there was a direct linear correlation between the two in the range of $0-0.5 \mu \mathrm{g}$ of SOD $(2500 \mathrm{U} / \mathrm{mg})($ Fig. $1 B$ ) as previously described by Misra and Fridovich (25). We measured $\mathrm{Cu}, \mathrm{Zn}$-SOD activity of PMN ho- 
mogenates by this method using $0.05,0.1$, and $0.15 \mu \mathrm{g}$ of human erythrocyte $\mathrm{Cu}, \mathrm{Zn}-\mathrm{SOD}$ to produce a standard line in each assay. The results are shown in Table 1 . SOD activity of the VLBW infants or the term-neonatal PMN was significantly lower than that of the adults' PMN $(p<0.005)$.

Although the NBT reduction assay on PAGE was useful to measure $\mathrm{Cu}, \mathrm{Zn}-\mathrm{SOD}$ activity in PMN, we also measured the content of $\mathrm{Cu}, \mathrm{Zn}$-SOD using a MAb against human $\mathrm{Cu}, \mathrm{Zn}-\mathrm{SOD}$ to verify the NBT reduction assay. Again, the content of SOD in PMN of the term newborn infants or the VLBW infants was significantly lower than that in the adults' PMN $(p<0.005)$ (Table 1).

Figure 2 represents the correlation between the SOD measured with ELISA and the SOD activity determined with the NBT reduction assay on PAGE. There was a significant direct correlation between the values by two methods $(r=0.84, p<0.005$, linear regression analysis).

$\mathrm{O}_{2}^{-}$production rate of $P M N$. The $\mathrm{O}_{2}^{-}$production rates of PMN of the VLBW infants, the healthy term newborn infants, and the adults are shown in Table 2. PMA-induced $\mathrm{O}_{2}{ }^{-}$production rates of PMN obtained from the VLBW infants at 0,6 , or $30 \mathrm{~d}$ of age were similar to that of the adults' PMN. The PMAor FMLP-induced $\mathrm{O}_{2}^{-}$production rate of PMN obtained from the VLBW infants at $0 \mathrm{~d}$ of age was significantly higher than that

A

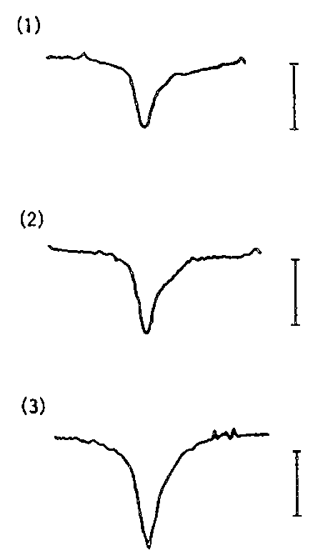

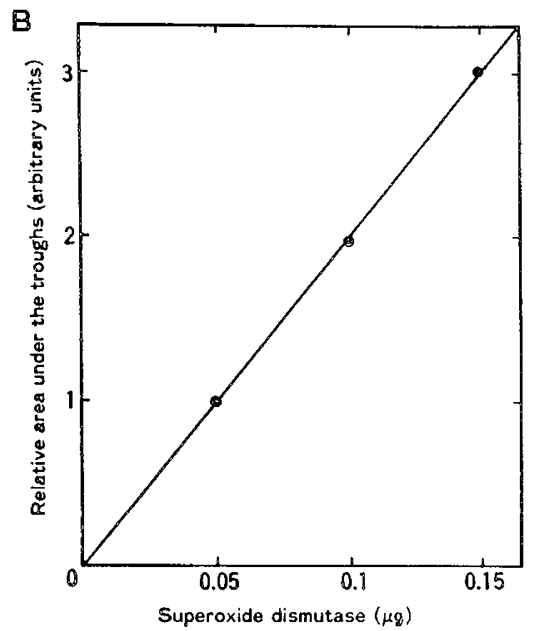

Fig. 1. $A$, densitometric scans of PAGE stained for SOD activity. The gel containing (1) 0.05 , (2) 0.1 , or (3) $0.15 \mu \mathrm{g}$ of $\mathrm{Cu}, \mathrm{Zn}-\mathrm{SOD}$ from human erythrocytes was scanned at $560 \mathrm{~nm}$. The area under the trough represents the quantity of SOD activity. This represents typical results from 10 similar independent experiments. The scale in the figure represents $0.1 \triangle \mathrm{OD}$ at $560 \mathrm{~nm}$. $B$, estimation of SOD activity. The $\mathrm{Cu}, \mathrm{Zn}-$ SOD-containing areas under the troughs produced by densitometric scanning of the gel were plotted against the quantity of SOD applied to the gel. The relative area under the trough was measured by weighing the tracing paper.

Table 1. SOD activities and SOD contents in PMN obtained from VLBW infants, healthy term newborn infants, and adults*

\begin{tabular}{lrcc}
\hline & & $\begin{array}{c}\text { SOD activity } \\
\text { (U/mg } \\
\text { protein) }\end{array}$ & $\begin{array}{c}\text { SOD content } \\
(\mathrm{ng} / \mathrm{mg} \text { protein) }\end{array}$ \\
\hline VLBW infants & 6 & $6.8 \pm 0.9 \dagger$ & $173.0 \pm 16.2 \dagger$ \\
Term newborn infants & 10 & $6.6 \pm 0.6 \dagger$ & $170.4 \pm 16.3 \dagger$ \\
Adults & 10 & $10.3 \pm 0.6$ & $241.9 \pm 13.3$ \\
\hline
\end{tabular}

* The PMN homogenate was assayed for the activity with NBT reduction assay and the content of $\mathrm{Cu}, \mathrm{Zn}$-SOD with ELISA as described in "Materials and Methods." Values represent mean \pm SEM from the number of the subjects as indicated.

$\dagger p<0.005$ when compared to adults' values.

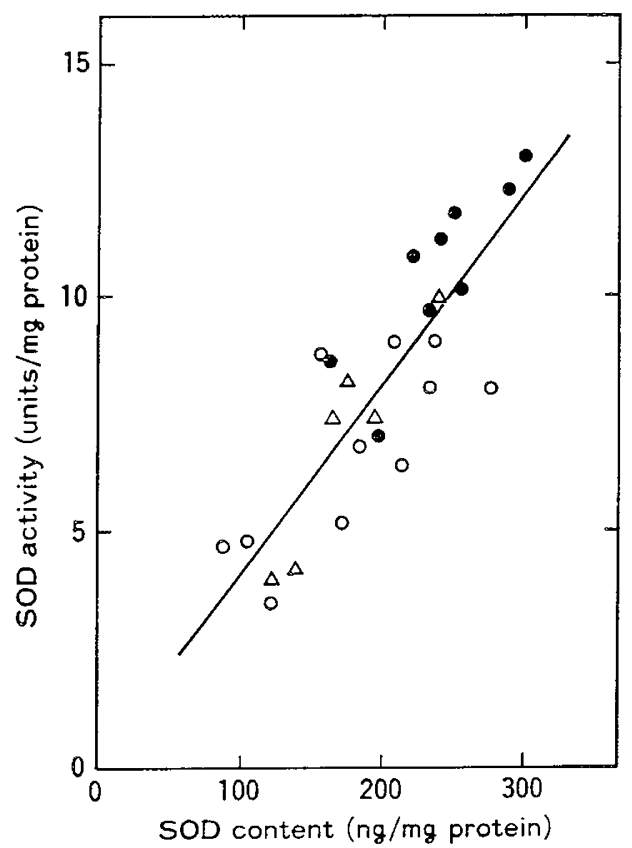

Fig. 2. The relationship of SOD activity measured with NBT reduction assay on PAGE and SOD content measured with ELISA in PMN from VLBW infants $(\triangle)$, healthy term newborn infants $(O)$, and adults ().

Table 2. $\mathrm{O}_{2}^{-}$production rates of PMN obtained from VLBW infants, healthy term newborn infants, and adults in response to PMA or FMLP*

\begin{tabular}{lrrrr} 
& & \multicolumn{3}{c}{ Stimulus } \\
\cline { 3 - 5 } & Age & PMA & \multicolumn{1}{c}{ FMLP } \\
& (d) & $n$ & $\left(\mathrm{nmol} / \mathrm{min} / 10^{6} \mathrm{PMN}\right)\left(\mathrm{nmol} / 3 \mathrm{~min} / 10^{6} \mathrm{PMN}\right)$ \\
\hline VLBW infants & 0 & 12 & $13.0 \pm 1.1 \dagger$ & $24.8 \pm 2.8 \dagger \ddagger$ \\
& 6 & 12 & $11.9 \pm 1.1$ & $20.4 \pm 2.8 \ddagger$ \\
& 30 & 9 & $15.2 \pm 2.1$ & $14.5 \pm 2.2$ \\
Term new- & 0 & 12 & $7.2 \pm 0.9 \ddagger$ & $10.4 \pm 1.5$ \\
$\quad$ born & 3 & 10 & $8.8 \pm 0.7 \ddagger$ & $15.9 \pm 1.6$ \\
Infants & 6 & 9 & $10.9 \pm 1.1 \S$ & $16.4 \pm 1.8$ \\
& & & \\
Adults & 19 & $13.2 \pm 0.8$ & $12.7 \pm 1.0$ \\
\hline
\end{tabular}

* PMN were suspended in PBS at $\mathrm{pH} 7.4\left(1 \times 10^{5} \mathrm{PMN} / \mathrm{mL}\right)$ containing $20 \mu \mathrm{M}$ cytochrome $\mathrm{C}$ and $5 \mathrm{mM}$ glucose. And PMN were stimulated by either $0.1 \mu \mathrm{g} / \mathrm{mL}$ PMA or $4 \mathrm{nM}$ FMLP. Spectrophotometric measurement of $\mathrm{O}_{2}^{-}$dependent cytochrome $\mathrm{C}$ reduction was performed as described in "Materials and Methods." Values represent mean \pm SEM from the number of the subjects as indicated.

$\dagger p<0.005$ when compared to term newborn infants' values at $0 \mathrm{~d}$ of age.

$\ddagger p<0.005, \S p<0.05$ when compared to adults' values.

of PMN obtained from the term newborn infants at $0 \mathrm{~d}$ of age $(p<0.005)$. The PMA-induced $\mathrm{O}_{2}{ }^{-}$production rate of the term neonatal PMN at $0 \mathrm{~d}$ of age was significantly lower than that of the adults' PMN $(p<0.005)$, and increased with age, but it was still lower than that of the adults' PMN at 3 and $6 \mathrm{~d}$ of age $(p<$ 0.005 and $p<0.05$, respectively).

The FMLP-induced $\mathrm{O}_{2}^{-}$production rate of PMN obtained from the VLBW infants at $0 \mathrm{~d}$ of age was significantly higher than that of the adults' PMN $(p<0.005)$, and decreased with their age to be equal to the adults' PMN value at $6 \mathrm{~d}$ of age. The FMLP-induced $\mathrm{O}_{2}{ }^{-}$production rate of the term neonatal PMN 
Table 3. $\mathrm{O}_{2}^{-}$production, $\mathrm{H}_{2} \mathrm{O}_{2}$ release, and the conversion rate from $\mathrm{O}_{2}^{-}$to $\mathrm{H}_{2} \mathrm{O}_{2}$ of PMN obtained from healthy term newborn infants, and adults*

\begin{tabular}{lcccc}
\hline & $n$ & $\begin{array}{c}\mathrm{O}_{2}^{-} \text {production } \\
\text { (nmol/min/10 }\end{array}$ & $\begin{array}{c}\mathrm{H}_{2} \mathrm{O}_{2} \text { release } \\
\text { (nmol/min/10 })\end{array}$ & $\begin{array}{c}\text { Conversion rate } \\
\text { from } \mathrm{O}_{2}{ }^{-} \text {to } \mathrm{H}_{2} \mathrm{O}_{2}\end{array}$ \\
\hline Term newborn infants & 6 & $6.8 \pm 1.3 \dagger$ & $1.0 \pm 0.1 \ddagger$ & $0.17 \pm 0.03$ \\
Adults & 6 & $12.4 \pm 1.4$ & $1.3 \pm 0.1$ & $0.11 \pm 0.02$ \\
\hline
\end{tabular}

* PMN were suspended in Krebs-Ringer bicarbonate buffer at pH $7.4\left(2.5 \times 10^{5} \mathrm{PMN} / \mathrm{mL}\right)$ containing $2 \mu \mathrm{M}$ scopoletin, $20 \mathrm{nM}$ horseradish peroxidase, and $5 \mathrm{mM}$ glucose, and were stimulated by $0.1 \mu \mathrm{g} / \mathrm{mL}$ PMA. The amount of $\mathrm{H}_{2} \mathrm{O}_{2}$ released was determined by measuring the decrease of fluorescence of scopoletin. The peak excitation and emission wave lengths of scopoletin were 355 and $460 \mathrm{~nm}$, respectively. Values represent mean \pm SEM from the number of the subjects as indicated.

$\dagger p<0.01, \ddagger p<0.05$ when compared to adults' values.

increased with their age, but there was no significant difference as compared with the adults' values.

$\mathrm{H}_{2} \mathrm{O}_{2}$ release and the conversion rate from $\mathrm{O}_{2}^{-}$to $\mathrm{H}_{2} \mathrm{O}_{2}$ of $P M N . \mathrm{H}_{2} \mathrm{O}_{2}$ release and the conversion rate from $\mathrm{O}_{2}{ }^{-}$to $\mathrm{H}_{2} \mathrm{O}_{2}$ of PMN obtained from the term newborn infants at $0 \mathrm{~d}$ of age and the adults are shown in Table 3. Again, the PMA-induced $\mathrm{O}_{2}{ }^{-}$production rate of PMN obtained from the term newborn infants at $0 \mathrm{~d}$ of age was significantly lower than that of the adults' PMN $(p<0.01)$. Also the amount of $\mathrm{H}_{2} \mathrm{O}_{2}$ produced by the neonatal PMN was significantly lower than that produced by the adults' PMN $(p<0.05)$. Although the conversion rate from $\mathrm{O}_{2}{ }^{-}$to $\mathrm{H}_{2} \mathrm{O}_{2}$ of the neonatal PMN was slightly higher than that of the adults' PMN, there was no statistically significant difference $(p>0.1)$.

\section{DISCUSSION}

Strauss et al. (23) demonstrated that SOD activity in PMN measured by the xanthine oxidase-cytochrome $\mathrm{C}$ system was similar in newborn infants, their mothers, and adult controls. However, their assay was not appropriate to measure SOD activity in crude PMN homogenates, because the mixture included other substances capable of directly reducing cytochrome C (24).

We could not obtain reliable results with the same method. To solve this problem, we used an NBT reduction assay on PAGE, and the results indicated a high correlation with the SOD content measured by ELISA. Accordingly, both methods are useful for measuring $\mathrm{Cu}, \mathrm{Zn}$-SOD in a very small quantity of crude extracts. In our study, both the activity and the content of $\mathrm{Cu}, \mathrm{Zn}-\mathrm{SOD}$ of PMN of the term newborn infants and the VLBW infants were lower than the adults' PMN (Table 1). Decreased activity and content of $\mathrm{Cu}, \mathrm{Zn}$-SOD in the neonatal PMN might be attributed to the fact that newborn infants have a lower serum copper concentration than adults (26).

There have been several reports studying decreased functions of PMN caused by autooxidative reactions. Decreased PMN functions such as chemotaxis, phagocytosis, and bactericidal activity can be induced by exposing PMN to oxidants (27). Skosey et al. (28) reported that products of oxidative metabolism adversely influenced lysosomal enzyme release from PMN and SOD retrieved enzyme release in those cells. PMN preexposed to cytotoxins showed decreased spontaneous and chemotactic migratory responses, whereas these changes were not observed in chronic granulomatous disease patients (29).

We have shown that the conversion rate from $\mathrm{O}_{2}^{-}$to $\mathrm{H}_{2} \mathrm{O}_{2}$ of the neonatal PMN was similar to that of the adults' PMN (Table 3). This finding suggests that neonatal PMN have an equal ability to convert $\mathrm{O}_{2}^{-}$to $\mathrm{H}_{2} \mathrm{O}_{2}$ to adults' $\mathrm{PMN}$, although the neonatal PMN had a lower SOD activity than the adults' PMN (Table 1). There are two possible explanations for these results: 1) $\mathrm{O}_{2}{ }^{-}$is dismutated more spontaneously than enzymatically in PMN, or, 2) the concentrations of SOD in the microenvironment in PMN are sufficient to convert $\mathrm{O}_{2}^{-}$in both term newborn infants and adults, although the total content is different between the two. In either case, the low content of $\mathrm{Cu}, \mathrm{Zn}-\mathrm{SOD}$ in PMN of the term newborn infants or the VLBW infants may not account for the autooxidative damage. However, the term neonatal PMN generated a lower amount of $\mathrm{H}_{2} \mathrm{O}_{2}$ than the adults' $\mathrm{PMN}$ as expected from a decreased production rate of $\mathrm{O}_{2}{ }^{-}$, and this may have caused a decreased hydroxyl radical production (12) which resulted in defective bactericidal activity in the neonatal PMN.

There have been several reports studying the $\mathrm{O}_{2}{ }^{-}$production rate of neonatal PMN (8-12), but the results have been varied. Some studies have demonstrated equal $\mathrm{O}_{2}{ }^{-}$production rates of PMN from healthy term newborn infants when compared to adults' PMN (8-10). However, it was also reported that the $\mathrm{O}_{2}{ }^{-}$ production rate of $\mathrm{PMN}$ from infants delivered vaginally, or by cesarean section with labor, was lower than that of adults' PMN (11). And the $\mathrm{O}_{2}{ }^{-}$production rate was higher in $\mathrm{PMN}$ of neonates than that in adults' PMN when opsonized zymosan was used as a stimulant (12).

In this report, we have shown that the PMA-induced $\mathrm{O}_{2}^{-}$ production rate of PMN from the healthy term newborn infants was significantly lower than that of the adults' PMN (Table 2). However, the FMLP-induced $\mathrm{O}_{2}{ }^{-}$production rate of PMN from the healthy term newborn infants was similar to that of the adults' PMN (Table 2). The difference between the $\mathrm{O}_{2}{ }^{-}$production rate elicited by PMA or FMLP may be due to the different modes of action of these two stimuli. PMA directly stimulates protein kinase $\mathrm{C}$ in PMN, whereas FMLP binds the surface receptors on the PMN cell membranes to elicit phosphatidylinositol metabolism and subsequent responses (30-32). But the exact reason for the different results with these two stimulants is unclear.

The PMA- or FMLP-induced $\mathrm{O}_{2}^{-}$production rate of PMN from the VLBW infants at $0 \mathrm{~d}$ of age was higher than that of the term newborn infants' PMN $(p<0.005)$ (Table 2). PMN of stressed neonates have been reported to produce higher amounts of $\mathrm{O}_{2}^{-}$than those of adults or healthy term newborn infants (10). We did see a statistical difference in the $\mathrm{O}_{2}{ }^{-}$production rate between PMN of the VLBW infants with respiratory distress syndrome and those of the other VLBW infants $(p>0.2)$. The $\mathrm{O}_{2}{ }^{-}$production rate of PMN of the hypoglycemic VLBW infants did not differ from the values of the other VLBW infants $(p>$ $0.1)$. None of the VLBW infants was given any medication other than glucose infusion at the sampling time at $0 \mathrm{~d}$ of age. Therefore, the difference in the $\mathrm{O}_{2}{ }^{-}$production rate between the VLBW infants' PMN and the term infants' PMN may not be attributed to specific complication such as respiratory distress and hypoglycemia.

The exact reason that the VLBW infants' PMN had a higher $\mathrm{O}_{2}{ }^{-}$production rate than did the term infants' $\mathrm{PMN}$ is unclear. However, $\mathrm{O}_{2}{ }^{-}$may be one of the major causes of retinopathy of prematurity and bronchopulmonary dysplasia, which are known as the side effects of the use of oxygen as a therapeutic agent (33, 34). The fact that PMN of the VLBW infants had the capacity to produce higher amounts of $\mathrm{O}_{2}{ }^{-}$than that of healthy term newborn infants may indicate that PMN contribute to the occurrence of bronchopulmonary dysplasia or retinopathy of prematurity of the VLBW infants. The exact role of PMN in triggering these diseases remains to be clarified. 
Acknowledgments. The authors thank Dr. T. Uda (Ube Industries) for his generous gift of $\mathrm{MAb}$ against human $\mathrm{Cu}, \mathrm{Zn}$ SOD and Mr. Y. Ogoshi (Arrows) for manufacturing SA-1.

\section{REFERENCES}

1. Babior BM 1978 Oxygen-dependent microbial killing by phagocytes. $N$ Engl J Med 298:659-668

2. Miller ME 1969 Phagocytosis in the newborn infant: humoral and cellular factors. J Pediatr 74:255-259

3. Mills EL, Thompson T, Bjorksten B, Filipovich D, Quie PG 1979 The chemiluminescence response and bactericidal activity of polymorphonuclear neutrophils from newborns and their mothers. Pediatrics 63:429-434

4. Coen R, Grush O, Kauder E 1969 Studies of bactericidal activity and metabolism of the leukocyte in full-term neonates. J Pediatr 75:400-406

5. Chirico G, Marconi M, Amici MD, Gasparoni A, Mingrat G, Chiara A, Rondini G, Ugazio AG 1985 Deficiency of neutrophil bactericidal activity in term and preterm infants. Biol Neonate 47:125-129

6. Wright WC, Ank BJ, Herbert J, Stiehm ER 1975 Decreased bactericidal activity of leukocytes of stressed newborn infants. Pediatrics 56:579-584

7. Shigeoka AO, Santos JI, Hill HR 1979 Functional analysis of neutrophil granulocytes from healthy, infected, and stressed neonates. J Pediatr 95:454460

8. Gahr M, Blanke R, Speer CP 1985 Polymorphonuclear leukocyte function in term and preterm newborn infants. Biol Neonate 48:15-20

9. Strauss RG, Snyder EL 1983 Activation and activity of the superoxidegenerating system of neutrophils from human infants. Pediatr Res 17:662664

10. Shigeoka AO, Charette RP, Wyman ML, Hill HR 1981 Defective oxidative metabolic responses of neutrophils from stressed neonates. J Pediatr 98:392398

11. Frazier JP, Cleary TG, Pickering LK, Kohl S, Ross PJ 1982 Leukocyte function in healthy neonates following vaginal and cesarean section deliveries. $J$ Pediatr 101:269-272

12. Ambruso DR, Altenburger KM, Johnston RB 1979 Defective oxidative metabolism in newborn neutrophils: discrepancy between superoxide anion and hydroxyl radical generation. Pediatrics 64:722-725

13. Salin ML, McCord JM 1974 Superoxide dismutases in polymorphonuclear leukocytes. J Clin Invest 54:1005-1009

14. Babior BM, Curnutte JT, Kipnes RS 1975 Biological defense mechanisms: evidence for the participation of superoxide in bacterial killing by xanthine oxidase. J Lab Clin Med 85:235-244

15. Gabig TG, Babior BM 1982 Oxygen-dependent microbial killing by neutrophils. In: Oberley LW (eds) Superoxide Dismutase, Vol 2. CRC Press Inc, Boca Raton, FL, pp 1-13

16. Drath DB, Karnovsky ML 1974 Bactericidal activity of metal-mediated peroxide-ascorbate systems. Infect Immun 10:1077-1083
17. Rosen H, Klebanoff SJ 1979 Bactericidal activity of a superoxide aniongenerating system: a model for the polymorphonuclear leukocyte. J Exp Med 149:27-39

18. Hill HR 1987 Biochemical, structural, and functional abnormalities of polymorphonuclear leukocytes in the neonate. Pediatr Res 22:375-382

19. Lowry OH, Rosebrough NJ, Farr AL, Randall RJ 1951 Protein measurement with the Folin phenol reagent. J Biol Chem 193:265-275

20. Laemmli UK 1970 Cleavage of structural proteins during the assembly of the head of bacteriophage T4. Nature 227:680-685

21. Nakamura H, Uetani Y, Komura M, Takada S, Sano K, Matsuo T 1987 Inhibitory action of bilirubin on superoxide production by polymorphonuclear leukocytes. Biol Neonate 52:273-278

22. Root RK, Metcalf JA, Oshino N, Chance B $1975 \mathrm{H}_{2} \mathrm{O}_{2}$ release from human granulocytes during phagocytosis. J Clin Invest 55:945-955

23. Strauss RG, Snyder EL, Wallace PD, Rosenberger TG 1980 Oxygen-detoxifying enzymes in neutrophils of infants and their mothers. J Lab Clin Med 95:897-904

24. Fridovich I 1982 Measuring the activity of superoxide dismutases: an embarrassment of riches. In: Oberley LW (eds) Superoxide Dismutase, Vol 1. CRC Press Inc, Boca Raton, FL, pp 69-77

25. Misra HP, Fridovich I 1977 Superoxide dismutase and peroxidase: a positive activity stain applicable to polyacrylamide gel electropherograms. Arch Biochem Biophys 183:511-515

26. Hillman LS 1981 Serial serum copper concentrations in premature and SGA infants during the first 3 months of life. $J$ Pediatr 98:305-308

27. Baehner RL, Boxer LA, Allen JM, Davis J 1977 Autooxidation as a basis for altered function by polymorphonuclear leukocytes. Blood 50:327-335

28. Skosey JL, Chow DC, Nusinow S, May J, Gestautas V, Niwa Y 1981 Effect of oxygen tension on human peripheral blood leukocytes: lysosomal enzyme release and metabolic responses during phagocytosis. J Cell Biol 88:358-363

29. Nelson RD, McCormack RT, Fiegel VD, Herron M, Simmons RL, Quie PG 1979 Chemotactic deactivation of human neutrophils: possible relationship to stimulation of oxidative metabolism. Infect Immun 23:282-286

30. Wolfson M, McPhail LC, Nasrallah VN, Snyderman R 1985 Phorbol myristate acetate mediates redistribution of protein kinase $C$ in human neutrophils: potential role in the activation of the respiratory burst enzyme. $J$ Immunol 135:2057-2062

31. Berridge MJ, Irvine RF 1984 Inositol triphosphate, a novel second messenger in cellular signal transduction. Nature 312:315-321

32. Volpi M, Yassin R, Naccache PH, Sha'affi RI 1983 Chemotactic factor causes rapid decreases in phosphatidylinositol,4,5,-bisphosphate and phosphatidylinositol 4-monophosphate in rabbit neutrophils. Biochem Biophys Res Commun 112:957-964

33. Feeney L, Berman ER 1976 Oxygen toxicity: membrane damage by free radicals. Invest Ophthalmol 15:789-792

34. Rosenfeld W, Evans H, Concepcion L, Jhaveri R, Schaeffer H, Friedman A 1984 Prevention of bronchopulmonary dysplasia by administration of bovine superoxide dismutase in preterm infants with respiratory distress syndrome. J Pediatr 105:781-785 